\title{
Persepsi pasien gangguan jiwa tentang aspek positif dan negatif dari tindakan restrain fisik pada pasien rawat inap
}

\author{
Iskandar ${ }^{1}$, Winda Restu Anggraini², Budi Rahman ${ }^{3}$ \\ ${ }^{1}$ Akademi Keperawatan Yarsi Samarinda. Email: iskandarlorenzo99@yahoo.co.id \\ ${ }^{2}$ Akademi Keperawatan Yarsi Samarinda. Email: wiindarestua28@gmail.com \\ ${ }^{3}$ Rumah Sakit Jiwa Daerah Atma Husada Mahakam Propinsi Kaltim. \\ Email: budirachman79@yahoo.co.id
}

\begin{abstract}
Psychiatric inpatients' perceptions of positive and negative aspects of physical restraint
\end{abstract}

Background: Restrain carried out on mental hospital clients also has a negative impact, besides restrain also has a positive impact that clients are calmer, reduce risk hurt himself. Restrain the client can cause physical impacts on the client, edema, lesions, the risk of injury, incontinence, the appearance of the client is less neat, and often the basic human needs of the client are not met. In addition, clients also feel the psychological effects of anxiety, anger, fear and even physical and psychological trauma.

Purpose: To identify Psychiatric inpatients' perceptions of positive and negative aspects of physical restraint at Atma Husada Mahakam Hospital of Province East Kalimantan.

Methods: This study uses quantitative research methods with designs descriptive, the sample of the study was 46 respondents and the data collection in the form of a questionnaire lately was about the physical impact and psychological impact.

Results: The results of the study the majority of respondents 37 people $(72.5 \%)$ experienced physical impact in the category of positive impact. While the study of the majority of respondents 28 people $(60.9 \%)$ experienced a psychological impact on the positive impact category.

Conclusion: Physical impact on restrain action is more dominant in the impact category, while the psychological impact on restrain action is more dominant in the positive impact category. It is recommended that nursing service agencies, can foster nurses' confidence to improve management of restrain measures.

\section{Keywords: Psychiatric inpatients; Perceptions; Physical restraint; Violent behavior}

Pendahuluan: Restrain yang dilakukan pada klien di rumah sakit jiwa ternyata juga menimbulkan dampak negatif, selain itu restrain juga memiliki dampak positif yaitu klien jadi lebih cepat tenang, mengurangi risiko mencederai diriya sendiri. Restrain pada klien bisa menyebabkan dampak fisik bagi klien yaitu oedema, lesi, resiko terjadi cedera, inkontensia, penampilan klien kurang rapi, dan sering kali kebutuhan dasar manusia pada klien tidak terpenuhi. Selain itu klien juga merasakan dampak psikologis yaitu cemas, marah, takut bahkan trauma baik fisik maupun psikologis.

Tujuan: Mengidentifikasi gambaran dampak tindakan restrain pada klien dengan gangguan jiwa di RSJD Atma Husada Mahakam Propinsi Kalimantan Timur.

Metode: Penelitian ini menggunakan metode penelitian kuantitatif dengan desain deskriptif, sampel penelitian sebanyak 46 orang responden dan alat pengumpulan data berupa kuesioner berisi tentang dampak fisik dan dampak psikologis.

Hasil: Hasil penelitian mayoritas responden 37 orang $(72.5 \%)$ mengalami dampak fisik pada kategori dampak positif. Sedangkan penelitian mayoritas responden 28 orang $(60.9 \%)$ mengalami dampak psikologis pada kategori dampak positif. 
Persepsi pasien gangguan jiwa tentang aspek positif dan negatif dari tindakan restrain fisik pada pasien rawat inap

Simpulan : Dampak fisik pada tindakan restrain lebih dominan pada kategori dampak, sedangkan dampak psikologis pada tindakan restrain lebih dominan pada kategori dampak positif. Disarankan agar instansi pelayanan keperawatan, dapat menumbuhkan rasa percaya diri perawat untuk meningkatkan penatalaksanaan tindakan restrain. untuk meningkatkan pengetahuan dan dalam menjalankan penatalaksanaan tindakan restrain.

\section{Kata Kunci: Persepsi pasien; Gangguan jiwa; Tindakan restrain fisik; Pasien rawat inap}

\section{PENDAHULUAN}

Pada umumnya gangguan mental yang terjadi adalah gangguan kecemasan dan gangguan depresi.Diperkirakan $4,4 \%$ dari populasi global menderita gangguan depresi, dan $3,6 \%$ dari gangguan kecemasan World Health Organization (2017). Jumlah penderita gangguan jiwa di Indonesia mencapai 2,5 juta jiwa yang terdiri dari pasien dengan risiko perilaku kekerasan (Departemen Kesehatan Republik Indonesia, 2008). Penderita gangguan jiwa di Indonesia masih cukup besar, hasil Riset Kesehatan Dasar tahun 2013, menunjukan bahwa prevalensi gangguan jiwa berat prevalensinya sebanyak 1,7 per 1000 penduduk (sekitar 400.000 jiwa). Prevalensi gangguan jiwa berat atau skizofrenia di daerah pedesaan lebih tinggi dibandingkan di perkotaan (Kementerian Kesehatan Republik Indonesia, 2013). Peningkatan proporsi gangguan jiwa pada data yang didapatkan cukup signifikan jika dibandingkan dengan Riskesdas 2013, naik dari $1,7 \%$ menjadi $7 \%$. Penderita gangguan jiwa di Kota Samarinda pada tahun 2015 tercatat sebanyak 1345 orang penderita (Dinas Kesehatan Kota Samarinda, 2015; Kementerian Kesehatan Republik Indonesia, 2018).

Berdasarkan studi pendahuluan yang telah dilakukan oleh peneliti pada tanggal 16-19 November 2018 di RSJD Atma Husada Mahakam Propinsaaai Kaltim, didapatkan data restrain pada tahun 2017 sebanyak 198 tindakan restrain yang dilakukan, sedangkan tahun 2018 mulai dari bulan Januari sampai bulan Oktober sebanyak 85 tindakan restrain yang dilakukan. Berdasarkan wawancara yang dilakukan peneliti kepada kepala ruangan dan perawat di IGD bahwa klien dengan menunjukan gejala agresif dan perilaku kekerasan atau amuk saat dirumah,, sehingga klien dibawa ke rumah sakit akan dilakukan penanganan awal yaitu restrain atau fiksasi, setelah di restrain klien diberikan terapi farmakologi oleh dokter.

Kepala ruangan dan perawat di ruang perawatan saat wawancara mengatakan kepada peneliti, restrain dilakukan kepada klien yang mulai merasa gelisah, mengamuk yang membahayakan diri klien atau orang lain dan ada juga klien yang meminta sendiri untuk diikat karena klien sudah mulai mendengar suara-suara yang menyuruh klien mengamuk. Lama restrain yang dilakukan tergantung keadaan klien ada yang 6-8 jam klien sudah tenang setelah di restrain dan ada juga yang 2-3 hari baru bisa tenang. Menurut kepala ruangan dan perawat ada dampak restrain yang dilakukan yaitu menimbulkan bekas bahkan lesi pada kaki atau tangan yang diikat, dan klien takut tidak mau di ikat.

Restrain yang dilakukan pada klien di rumah sakit jiwa ternyata juga menimbulkan dampak negatif, dampak restrain bisa terjadi pada pihak klien sendiri juga pihak perawat yang melakukan tindakan ini. Selain dampak negatif saat di restrain tetapi juga memiliki dampak positif yaitu klien jadi lebih cepat tenang, mengurangi risiko mencederai diriya sendiri. Restrain pada klien bisa menyebabkan dampak fisik bagi klien yaitu oedema, lesi, resiko terjadi cedera, inkontensia, penampilan klien kurang rapi, dan sering kali kebutuhan dasar manusia pada klien tidak terpenuhi. Selain itu klien juga merasakan dampak psikologis yaitu cemas, marah, takut bahkan trauma baik fisik maupun psikologis. Penelitian menunjukan bahwa dari 11 kali prosedur restrain, $68,7 \%$ klien mengalami cedera secara fisik, dan $31,5 \%$ klien mengalami cedera psikologis (Pambudi, 2014). 
Persepsi pasien gangguan jiwa tentang aspek positif dan negatif dari tindakan restrain fisik pada pasien rawat inap

Perawat yang bekerja di Instalasi Gawat Darurat (IGD), ruangan UPIP maupun ruangan perawatan lainnya yang berada di rumah sakit jiwa, seringkali menjadi korban dari perilaku kekerasan yang dilakukan oleh klien, oleh karena itu perawat yang bekerja di rumah sakit jiwa harus mampu mengkaji pasien yang berisiko melakukan perilaku kekerasan. Perawat juga harus efektif mampu menangani klien sebelum, selama dan sesudah perilaku kekerasan berlangsung. Perawat dituntut untuk mempunyai pengetahuan, keterampilan dan sikap untuk melakukan manajemen kekerasan, perawat wajib untuk menyediakan manajemen kekerasan dan agresi dengan benar, seperti pelatihan, edukasi, yang fokus pada identifikasi awal, dan menggunakan restrain yang benar sesuai Standar Prosedur Operasional (SPO).

Tujuan penelitian ini mengidentifikasi gambaran dampak tindakan restrain pada klien dengan gangguan jiwa di RSJD Atma Husada Mahakam Propinsi Kalimantan Timur.

\section{METODE PENELITIAN}

Penelitian ini menggunakan metode penelitian kuantitatif dengan desain deskriptif dengan variabel yang diteliti adalah gambaran dampak tindakan restrain pada klien dengan gangguan jiwa. Jumlah sampelnya sebanyak 46 pasien gangguan jiwa yang kondisinya sudah stabil dan tidak mempunyai gejala psikotik. Penelitian dilakukan pada bulan Februari sampai dengan Maret 2019, di RSJD Atma Husada Mahakam Propinsi Kaltim.

Alat pengumpulan data berupa observasi fisik dan kuesioner dengan jumlah 40 pertanyaan yang terdiri dari 30 pernyataan tentang dampak psikologis dan 10 pernyataan tentang dampak fisik dari tindakan restrain. Kuesioner ini sudah pernah digunakan pada peneliti sebelumnya dan di uji coba kembali oleh peneliti dan mendapatkan hasil uji validitas 0,671-0,984 dan hasil uji reliabilitas Alpha-Cronbach sebesar 0,768 (Sujarwo \& Livana, 2017). 


\section{HASIL}

Tabel 1. Distribusi Frekuensi Variabel Berdasarkan Karakteritik Pasien $\mathrm{N}=46$

\begin{tabular}{|c|c|c|}
\hline Karakteristik Pasien & Jumlah (n) & Persentase (\%) \\
\hline \multicolumn{3}{|l|}{ Jenis Kelamin } \\
\hline Laki-laki & 28 & 54.9 \\
\hline Perempuan & 18 & 35.3 \\
\hline \multicolumn{3}{|l|}{ Pendidikan } \\
\hline SD & 8 & 15.7 \\
\hline SMP & 12 & 23.5 \\
\hline SMU/SMA/MA & 22 & 43.1 \\
\hline Perguruan Tinggi & 1 & 2.0 \\
\hline Tidak Sekolah & 3 & 5.9 \\
\hline \multicolumn{3}{|l|}{ Diagnosa Keperawatan } \\
\hline Halusinasi & 9 & 17.6 \\
\hline Perilaku Kekerasan & 32 & 62.7 \\
\hline Resiko Perilaku Kekerasan & 5 & 9.8 \\
\hline \multicolumn{3}{|l|}{ Lama dilawat } \\
\hline$\leq 1$ tahun & 22 & 47.8 \\
\hline$\geq 1$ tahun & 24 & 62.2 \\
\hline \multicolumn{3}{|l|}{ Umur } \\
\hline $5-11$ & 1 & 2.0 \\
\hline $12-16$ & 1 & 2.0 \\
\hline $17-25$ & 9 & 17.6 \\
\hline $26-35$ & 24 & 47.1 \\
\hline $36-45$ & 5 & 9.8 \\
\hline $46-55$ & 3 & 5.9 \\
\hline $56-65$ & 1 & 2.0 \\
\hline 65 ke atas & 2 & 3.9 \\
\hline
\end{tabular}

Berdasarkan hasil analisis pada Tabel 1 didapatkan bahwa sebagian besar responden, laki-laki yaitu 28 orang $(54.9 \%)$. Pendidikan mayoritas berpendidikan SMA sebanyak 22 orang (43.1\%). Diagnosa keperawatan responden sebagian besar yaitu perilaku kekerasan sebanyak 32 orang $(62.7 \%)$. Lama dirawat klien sebagian besar pasien yang dirawat lebih dari 1 tahun 24 orang $(62.2 \%)$ dan umur responden mayoritas umur 26-35 tahun sebanyak 24 orang $(47,1 \%)$. 
Persepsi pasien gangguan jiwa tentang aspek positif dan negatif dari tindakan restrain fisik pada pasien rawat inap

\section{Tabel 2. Persepsi Pasien Gangguan Jiwa Tentang Aspek Positif dan Negatif Dari Tindakan Restrain Fisik $\mathrm{N}=46$}

\begin{tabular}{lll}
\hline Persepsi Pasien & Jumlah (n) & Persentase (\%) \\
\hline Fisik & & \\
$\begin{array}{l}\text { a. Positif } \\
\text { b. Negatif }\end{array}$ & 37 & 72.5 \\
& 9 & 17.6 \\
Psikologis & & \\
a. Positif & 28 & 60.9 \\
b. Negatif & 18 & 39.1 \\
\hline
\end{tabular}

Hasil analisis dari tabel 2 menunjukan bahwa dampak fisik pada tindakan restrain lebih dominan pada dampak positif sebanyak 37 orang $(72.5 \%)$ dan dampak negatif sebanyak 9 orang (17.6\%). Sedangkan dampak psikologis tindakan restrain lebih dominan pada dampak positif sebanyak 28 orang $(60.9 \%)$ dan dampak negatif sebanyak 18 orang $(39.1 \%)$.

\section{PEMBAHASAN}

Hasil penelitian ini menunjukan bahwa dampak restrain pada responden tidak hanya berdampak pada psikologis pasien tetapi juga berdampak pada fisik pasien. Hasil penelitian yang telah dilakukan menunjukan dampak psikologis dan fisik lebih ke dampak positif. Hasil penelitian ini berbanding terbalik dengan hasil penelitian sebelumnya dimana dampak pelaksanaa restrain pada pasien dapat menyebabkan terjadinya trauma baik secara fisik ataupun psikologis, bahkan dapat menyebabkan terjadinya cedera/meninggal dunia (Miller, 2012). Beberapa penelitian sebelumnya hasilnya sejalan yang menunjukan sebagian besar mempunyai dampak psikologis dan fisik menyatakan negativf pada tindakan restrain, dimana tidak ditemukan cedera secara fisik seperti luka pada pergelangan tangan ataupun pada pergelangan kaki, prosedur restrain memberikan efek samping bagi pasien, walaupun sebagian besar tidak memberikan efek samping, namun masih ada prosedur restrain yang memberikan efek samping yang positif dan terbukti efektif untuk mengurangi perilaku kekerasan (Sujarwo, \& Livina, 2017; Pambudi, 2014; Putri, Elita, \& Indriati, 2018).
Penelitian ini di dapatkan data dampak positif baik dari dampak fisik dan dampak psikologis. Dampak positif pada fisik adalah tidak adanya di dapatkan bekas luka atau lesi pada ekstermitas gerak pasien, sedangkan untuk dampak positif pada psikologis yaitu pasien menjadi lebih cepat tenang dan tidak hanya pada saat gaduh gelisah saja pasien di restrain tetapi pasien juga terkadang meminta untuk di ikat karena mulai mendengarkan suara-suara dan menurutnya dengan diikat akan menjauhkannya dari resiko mengamuk dan melukai dirinya sendiri dan berharap agar bisa lebih tenang.

Dampak positif dari tindakan restrain tidak lepas dari tindakan keperawatan yang dilakukan oleh perawat yang sesuai dengan Standar Prosedur Operasional (SPO). SPO untuk durasi pemasangan restrain paling lama 12 jam pemasangan restrain yang sesuai dengan kriteria waktu penggunaan resrain yaitu : 4 jam untuk dewasa $\geq 18$ tahun, 2 jam untuk anak remaja usia 9-12 tahun. Menghindari terjadinya efek samping selama tindakan restrain pada klien gangguan jiwa, perawat diberikan tanggung jawab untuk merawat kesehatan fisik klien selama tindakan restrain dilakukan perawat juga haris memberikan asuhan keperawatan yang nyaman, aman, dan manusiawi, terhadap klien yang direstrain jika klien berada dalam pengendalian mekanis, perawat akan mencoba melepaskan restrain setiap jam selama minimal 10 menit untuk memungkinkan rentang latihan gerak dan memeriksan integritas kulit (Mustaqin, \& Dwiantoro, 2018).

Restrain termasuk strategi pengekangan atau pengikatan, walaupun secara etik restrain masih menjadi perdebatan dalam melanggar hak asasi manusia. Restrain masih menjadi tindakan yang

lskandar' Akademi Keperawatan Yarsi Samarinda. Email: iskandarlorenzo99@yahoo.co.id

Winda Restu Anggraini ${ }^{2}$ Akademi Keperawatan Yarsi Samarinda. Email : wiindarestua28@gmail.com

Budi Rahman ${ }^{3}$ Rumah Sakit jiwa Daerah Atma Husada Mahakam Propinsi Kaltim. Email: budirachman79@yahoo.co.id 
efektif untuk menunrunkan perilaku kekerasan pada pasien gangguan jiwa. Kinerja perawat dirumah sakit Atma Husada Mahakam sudah sangat baik dimana sudah mampu menerapkan SPO tentang restrain, selain itu perawat juga sudah mengikuti pelatihan maupun seminar tentang tindakan kegawatdaruratan psikiatri, sehingga dampak restrain secara psikologis maupun secara fisik tidak terdapat dampak negatif.

Pelatihan dapat dipandang sebagai bentuk investasi, sehingga setiap rumah sakit yang ingin berkembang hendaknya memiliki program pendidikan dan pelatihan bagi perawat secara kontinyu khususnya keperawatan jiwa. Pelatihan yang dilakukan secara terprogram dan didukung oleh pihak rumah sakit dengan tujuan untuk menghasilkan perawat yang mampu melaksanakan tugas dan pekerjaannya lebih efektif dan sesuai dengan standar dalam melakukan tindakan restrain. Meningkatnya pengetahuan dan kemampuan perawat, akan berpengaruh terhadap cara kerja perawat menjadi lebih baik dan dapat mencapai hasil yang maksimal baik bagi individu sendiri maupun rumah sakit dalam memberikan pelayanan keperawatan. Pelatihan dapat membantu pegawai untuk bekerja dan berperilaku lebih baik, membuat keputusan lebih baik, serta meningkatkan kemampuan dan percaya diri dalam menyelesaikan berbagai masalah yang dihadapi dalam pekerjaan (Siagian, 2008; Fitriastuti, 2013; Marpaung, 2014).

Kompetensi dasar yang harus dimiliki oleh setiap perawat Indonesia pada semua jenjang pendidikan di antaranya adalah menwujudkan dan memelihara lingkungan keperawatan yang aman melalui jaminan kualitas dan menejemen resiko (patient safety) melakukan, melakukan tindakan dengan adanya pelatihan perawat. perawat yang berkompeten dapat mengurangi resiko adanya kecelakaan ketika terjadinya restrain dan seklusi (Efendi, 2008; Simamora, 2009; Bowers \& Crowder, 2012).

Perawat merupakan tenaga kesehatan yang lebih banyak $40 \%-60 \%$ di rumah sakit, sehingga perawat harus kompeten dalam memberikan tindakan keperawatan khususnya pada klien gangguan jiwa. Perawat sebagai unsur sumber daya manusia terbesar dari petugas kesehatan, memiliki peran utama dalam menyediakan pelayanan keperawatan berkelanjutan, berkualitas tinggi untuk klien (Departemen Kesehatan
Republik Indonesia, 2008; Yaghoubi, \& Javadi, 2013). Pelayanan yang baik akan mampu memberikan kepuasan kepada klien, keluarga dan masyarakat, sehingga tujuan rumah sakit tercapai yaitu mampu memberikan pelayanan yang berkualitas dan bermutu kepada masyarakat.

\section{SIMPULAN}

Dampak fisik pada tindakan restrain lebih dominan untuk dampak positif dengan presentase $72.5 \%$, sedangkan dampak psikologis pada tindakan restrain untuk dampak positif sebanyak $60.9 \%$.

\section{SARAN}

Untuk instansi pelayanan keperawatan, dapat menumbuhkan rasa percaya diri perawat untuk meningkatkan pengetahuan dan dalam menjalankan penatalaksanaan tindakan restrain, serta ,meningkatkan pemberian pelayanan dalam asuhan keperawatan kepada klien sesuai Standar Prosedur Oprasional (SPO). Instansi pendidikan keperawatan, diharapkan dapat menambahkan dalam praktikum dalam mata kuliah keperawatan jiwa serta seminar-seminar ilmiah khususnya tindakan restrain dan keperawatan jiwa pada umumnya

\section{DAFTAR PUSTAKA}

Bowers, L., \& Crowder, M. (2012). Nursing staff numbers and their relationship to conflict and containment rates on psychiatric wards- $A$ cross sectional time series Poisson regression study. International Journal of Nursing Studies, 49(1), 15-20.

Departemen Kesehatan Republik Indonesia (2008). Profil Kesehatan RI. Jakarta: Depkes RI.

Dinas Kesehatan Kota Samarinda. (2015). Profil Kesehatan Kota Samarinda 2015. Samarinda: Dinas Kesehatan Kota Samarinda

Efendi, N. F. (2008). Pendidikan dalam keperawatan. Jakarta: Salemba Medika.

lskandar' Akademi Keperawatan Yarsi Samarinda. Email: iskandarlorenzo99@yahoo.co.id

Winda Restu Anggraini ${ }^{2}$ Akademi Keperawatan Yarsi Samarinda. Email : wiindarestua28@gmail.com

Budi Rahman ${ }^{3}$ Rumah Sakit Jiwa Daerah Atma Husada Mahakam Propinsi Kaltim. Email: budirachman79@yahoo.co.id 
Persepsi pasien gangguan jiwa tentang aspek positif dan negatif dari tindakan restrain fisik pada pasien rawat inap

Fitriastuti, T. (2013). Pengaruh Kecerdasan Emosional, Komitmen Organisasional dan Organizational Citizenship Behavior terhadap Kinerja Karyawan. Jurnal Dinamika Manajemen, 4(2).

Kementerian Kesehatan Republik Indonesia. (2013). Riset kesehatan dasar (Riskesdas) 2013. Jakarta: Badan Penelitian dan Pengembangan Kesehatan.

Kementerian Kesehatan Republik Indonesia. (2018). Hasil Utama Riskesdas 2018. Kementerian Kesehatan Badan Penelitian dan Pengembangan Kesehatan, 248.

Marpaung, M. (2014). Pengaruh kepemimpinan dan Team work Terhadap kinerja karyawan Di koperasi sekjen kemdikbud senayan jakarta. Jurnal IImiah WIDYA, 1(1)

Miller, J. E. (2012). Too Significant to Fail: The Importance of State Behavioral Health Agencies in the Daily Lives of Americans with Mental IIIness, for their Families, and for their Communities. National Association of State Mental Health Program Directors

Mustaqin, M., \& Dwiantoro, L. (2018). Restrain yang efektif untuk mencegah cedera. Jurnal Keperawatan, 10(1), 19-27.
Pambudi, P. S. (2014). Efektivitas Tindakan Restrain Pada Pasien Perilaku Kekerasan Yang Menjalani Perawatan Di Unit Pelayanan Intensif Psikiatri (UPIP) RSJ Daerah Dr. Amino Gondohutomo Semarang Tahun 2013. In Prosiding Seminar Nasional \& Internasional (Vol. 2, No. 1).

Putri, D. S., Elita, V., \& Indriati, G. (2018). Pengaruh tindakan restraint terhadap skor rufa pada pasien dengan perilaku kekerasan. Jurnal Online Mahasiswa (JOM) Bidang IImu Keperawatan, 5, 236-242

Siagian, S.P. (2008). Manajemen Sumber Daya Manusia. Bumi Aksara

Simamora, N. R. H. (2009). Buku ajar pendidikan dalam keperawatan. EGC.

Sujarwo, S., \& Livana, P. H. (2017). Gambaran dampak tindakan restrain pasien gangguan jiwa. Jurnal Ilmiah Permas: Jurnal IImiah STIKES Kendal, 7(2), 45-53.

World Health Organization. (2017). Depression and other common mental disorders: global health estimates (No. WHO/MSD/MER/2017.2). World Health Organization

Yaghoubi, M., \& Javadi, M. (2013). Health promoting Hospitals in Iran: How it is. Journal of education and health promotion, 2.

lskandar' Akademi Keperawatan Yarsi Samarinda. Email: iskandarlorenzo99@yahoo.co.id

Winda Restu Anggraini ${ }^{2}$ Akademi Keperawatan Yarsi Samarinda. Email : wiindarestua28@gmail.com

Budi Rahman ${ }^{3}$ Rumah Sakit Jiwa Daerah Atma Husada Mahakam Propinsi Kaltim. Email: budirachman79@yahoo.co.id 